\title{
23. MOLECULAR PALAEONTOLOGY OF EASTERN MEDITERRANEAN SAPROPELS: EVIDENCE FOR PHOTIC ZONE EUXINIA ${ }^{1}$
}

\author{
H.-J. Bosch, 2,3 J.S. Sinninghe Damsté,, ${ }^{2,3}$ and J.W. de Leeuw ${ }^{2,3}$
}

\begin{abstract}
Organic geochemical data are presented for two Pliocene sapropels recovered during Ocean Drilling Program (ODP) Leg 160 in the Eastern Mediterranean Basin. One sapropel from Site 969 is exceptionally rich in organic carbon (TOC up to 30\%) and the other one, from Site 967, has a more typical organic carbon content (TOC up to $8 \%$ ). The majority of the solvent extractable organic matter of these sapropels can be ascribed to autochthonous sources. Higher plant-derived organic compounds are present in only minor amounts. Pyrolysis gas chromatography-mass spectrometry (GC-MS) analyses of the bulk organic matter also indicates that the contribution of terrestrial organic matter to these sapropels is insignificant. The presence of biomarkers derived from green sulfur bacteria, which are indicative of anoxygenic photosynthesis, show that during sapropel formation anoxia was not merely confined to the lower parts of the water column but, in fact, extended into the photic zone, resulting in an almost completely euxinic water column, a setting similar to the present-day Black Sea. Furthermore, it is proposed that these paleoenvironmental conditions have been a major controlling factor in the accumulation of organic matter in these sapropels.
\end{abstract}

\section{INTRODUCTION}

Sapropels are discrete layers with a thickness greater than $1 \mathrm{~cm}$, present in open marine pelagic sediments and containing more than $2 \%$ organic carbon by weight (Kidd et al., 1978). The formation and timing of eastern Mediterranean sapropels is controlled by astronomically induced insolation variations and coincides with the more humid periods at times of precession minima (e.g., Rossignol-Strick et al., 1982; Rossignol-Strick, 1985; Hilgen, 1991). Though it is generally accepted that the formation of Mediterranean sapropels is a result of hydrographical regimes associated with an increase in precipitation and runoff (e.g., Rossignol-Strick, 1985; Rohling and Gieskens, 1989), the actual mechanisms for the resulting sapropel formation are still a matter of debate (e.g., Emeis and Shipboard Scientific Party, 1996). For the eastern Mediterranean sapropels, as well as for many other organic carbon-rich marine sediments, causes of the organic carbon enrichment are often discussed in terms of (1) enhanced preservation of organic matter because of anoxic depositional environments (e.g., Demaison and Moore, 1980) and/or (2) increased primary productivity (e.g., Calvert, 1983; Pedersen and Calvert, 1990; Calvert et al., 1992). The combined effect of a higher, productivitydriven organic carbon flux to the seafloor, oxygen depletion in the deeper waters as a result of the bacterial decomposition of organic matter, and reduced reoxygenation due to a restricted circulation, all triggered by the same external (orbital) forcing, has recently been proposed as an explanation for the formation of the eastern Mediterranean sapropels (Emeis and Shipboard Scientific Party, 1996). The presence of an anoxic depositional environment during times of sapropel formation has been deduced from a variety of geochemical, sedimentological, and micropaleontological data (e.g., Bradley,

${ }^{1}$ Robertson, A.H.F., Emeis, K.-C., Richter, C., and Camerlenghi, A. (Eds.), 1998. Proc. ODP, Sci. Results, 160: College Station, TX (Ocean Drilling Program).

${ }^{2}$ Netherlands Institute for Sea Research (NIOZ), Division of Marine Biogeochemistry and Toxicology, P.O. Box 59, 1790 AB Den Burg, The Netherlands. Bosch@nioz.nl

${ }^{3}$ Utrecht University, Institute of Earth Sciences, Department of Geochemistry, P.O. Box 80.021, 3508 TA Utrecht, The Netherlands.
1938; Thunell et al., 1984; Howell et al., 1988; Passier et al., 1996). The extent to which the anoxic zone penetrates into the upper water column, however, is not clear.

Anoxic waters extending into the photic zone are thought to be an important phenomenon leading to the formation of organic-rich sediments in the Black Sea (Repeta et al., 1989; Sinninghe Damsté et al., 1993). The occurrence of such conditions in ancient depositional environments can be established by examining the sedimentary record for the presence of diagenetic products of specific pigments from green sulfur bacteria (Chlorobiaceae; e.g., Koopmans et al., 1996; Grice et al., 1996; van Kaam-Peters et al., unpubl. data; Sinninghe Damsté and Köster, unpubl. data). These bacteria are strictly anaerobic microorganisms that require an environment in which both light and $\mathrm{H}_{2} \mathrm{~S}$ are available (i.e., when anoxic, $\mathrm{H}_{2} \mathrm{~S}$-containing waters are present in the photic zone). Chlorobiaceae uniquely biosynthesize bacteriochlorophylls $c, d$, and $e$ and isorenieratene (I), pigments that are required to perform photosynthesis under extremely low light intensities. Because of their specific biosynthetic pathway, in which they fix carbon through the reverse tricarboxylic acid cycle (Quandt et al., 1977), their biomass is considerably enriched in ${ }^{13} \mathrm{C}$ relative to algal organic matter. The presence of ${ }^{13} \mathrm{C}$-enriched dia- and catagenetic products (e.g., II-V) of isorenieratene (I) in sediments therefore, provides a means of tracing the occurrence of photic zone euxinia in the geological record. It has recently been shown that, in the past, in marine paleoenvironments where large amounts of organic matter accumulated in sediments, photic zone anoxia may have been a much more common and widespread feature than had been previously thought (Koopmans et al., 1996).

It can be assumed that sapropel formation is related to photic zone anoxia at least for those sapropels exceptionally rich in organic carbon (TOC up to 30\%) which were recovered during ODP Leg 160. This could imply that these sapropels are modern analogues of the socalled black shales deposited in the past (Sinninghe Damsté and Köster, unpubl. data). If so, by studying eastern Mediterranean sapropels we can extend our understanding of black shale formation. To test this assumption, two organic-rich eastern Mediterranean sapropels have been analyzed for biomarker compounds, in particular 
for those indicative of photic zone anoxia (i.e., isorenieratene (I) derivatives) (Koopmans et al., 1996).

\section{MATERIAL AND METHODS Sample Description}

The samples used in this study are listed in Table 1, together with organic carbon content and extraction yields. The majority of the data presented in this study are derived from organic geochemical analyses of Sample 160-969E-6H-6, 34-35 cm.

\section{Extraction and Fractionation}

Approximately 1.5 to $2 \mathrm{~g}$ per sediment were lyophilized and finely ground. The samples were ultrasonically extracted using $8 \mathrm{~mL}$ of methanol $(\mathrm{MeOH})(4 \mathrm{x}), 8 \mathrm{~mL}$ of dichloromethane (DCM): $\mathrm{MeOH}$ $(1: 1 \mathrm{v} / \mathrm{v})(4 \mathrm{x})$ and $8 \mathrm{~mL}$ of DCM $(4 \mathrm{x})$. The extracts were combined and elemental sulfur was removed by stirring with activated copper $(24 \mathrm{~h})$. Aliquots of the total solvent extractable organic matter with a known amount of standards (Kohnen et al., 1990b) were separated on an activated $\mathrm{Al}_{2} \mathrm{O}_{3}$ packed column. An apolar fraction was collected by elution with four column volumes of hexane:DCM $(9: 1 \mathrm{v} / \mathrm{v})$ and a polar fraction was collected using four column volumes of DCM:MeOH $(1: 1 \mathrm{v} / \mathrm{v})$. The polar fraction was further separated by thin layer chromatography. The plate was developed (Skipski et al., $1965)$ with di-isopropylether/acetic acid (96:4 v/v) up to $75 \%$ of the plate and redeveloped with petroleum ether 40-60/ether/acetic acid $(89: 10: 1 \mathrm{v} / \mathrm{v})$. Six fractions $(\mathrm{P} 1, \mathrm{Rf}=0.85-1.00 ; \mathrm{P} 2, \mathrm{Rf}=0.75-0.85$; $\mathrm{P} 3, \mathrm{Rf}=0.50-0.75 ; \mathrm{P} 4, \mathrm{Rf}=0.35-0.50 ; \mathrm{P} 5, \mathrm{Rf}=0.20-0.35$ and $\mathrm{P} 6$, $\mathrm{Rf}=0.00-0.20)$ were isolated. The apolar fraction was further separated by argentation thin layer chromatography $\left(\mathrm{Ag}^{+} \mathrm{TLC}\right)$ using hexane as developer (Kohnen et al., 1990b). Four fractions (A1, Rf = $0.85-1.00 ; \mathrm{A} 2, \mathrm{Rf}=0.57-0.85 ; \mathrm{A} 3, \mathrm{Rf}=0.06-0.57$ and $\mathrm{A} 4, \mathrm{Rf}=$ $0.00-0.06)$ were isolated. An aliquot of the total solvent extractable organic matter as well as the P1 to P6 fractions were methylated with diazomethane and subsequently silylated with BSTFA in pyridine (1 $\mathrm{h}$ at $\left.60^{\circ} \mathrm{C}\right)$. The total solvent extractable organic matter was chromatographed on a small silica gel column with ethyl acetate to remove the very polar compounds before silylation. Polar fractions were also desulfurized with Raney nickel (Sinninghe Damsté et al., 1988).

\section{Instrumental Analyses}

Gas chromatography (GC) was performed on a Hewlett-Packard 5890 series II gas chromatograph equipped with a fused silica capillary column $(25 \mathrm{~m} \times 0.32 \mathrm{~mm})$ coated with CP Sil 5 (film thickness $0.12 \mu \mathrm{m})$. Helium was used as carrier gas. The samples were oncolumn injected at $70^{\circ} \mathrm{C}$ and the oven was subsequently programmed to $130^{\circ} \mathrm{C}$ at $20^{\circ} \mathrm{C} / \mathrm{min}$ and then at $4^{\circ} \mathrm{C} / \mathrm{min}$ to $310^{\circ} \mathrm{C}(20 \mathrm{~min})$. Gas chromatography-mass-spectrometry (GC-MS) was conducted on a Hewlett-Packard 5890 series II gas chromatograph connected to a VG Autospec Ultima mass spectrometer. GC conditions were the same as described above. The mass spectrometer was operated with an ionization energy of $70 \mathrm{eV}$, a mass range $\mathrm{m} / \mathrm{z} 50-800$ and a cycle time of $1.8 \mathrm{~s}$ (resolution 1000). Isotope ratio monitoring GC-MS (irm-GC/MS) analyses were performed on a DELTA-C irm-GC-MS system similar to one described previously (Hayes et al., 1990). A Hewlett-Packard 5890 series II gas chromatograph was equipped with a fused silica capillary column $(25 \mathrm{~m} \times 0.32 \mathrm{~mm})$ coated with CP Sil 5 (film thickness $0.12 \mu \mathrm{m}$ ). Helium was used as carrier gas. The samples were on-column injected at $70^{\circ} \mathrm{C}$, and the oven was subsequently programmed to $130^{\circ} \mathrm{C}$ at $20^{\circ} \mathrm{C} / \mathrm{min}$ and then at $4^{\circ} \mathrm{C} / \mathrm{min}$ to $310^{\circ} \mathrm{C}(20 \mathrm{~min})$. The isotopic values were calculated by integrating the mass 44,45 and 46 ion currents of the peaks produced by combustion of the chromatographically-separated compounds and that of
Table 1. Organic carbon content (\% TOC) and extraction yields (mg solvent extractable matter/g sediment) for the core samples used in this study.

\begin{tabular}{lccc}
\hline $\begin{array}{c}\text { Core, section, interval } \\
(\mathrm{cm})\end{array}$ & $\begin{array}{c}\mathrm{C}_{\text {org }} \\
(\%)^{*}\end{array}$ & $\begin{array}{c}\mathrm{CaCO}_{3} \\
(\%)^{*}\end{array}$ & $\begin{array}{c}\text { Extract yield } \\
(\mathrm{mg} \text { extract/g sediment })\end{array}$ \\
\hline 160-967C- & & & \\
6-2, 35.3-36.8 & 8.1 & 25.1 & 26.8 \\
160-969E- & & & \\
6H-6, 29-30 & 11.5 & 8.9 & 13.9 \\
6H-6, 32-33 & 26.6 & 16.0 & 102.7 \\
6H-6, 34-35 & 26.3 & 15.0 & 41.5 \\
6H-6, 36-37 & 22.9 & 19.5 & 59.3 \\
\hline
\end{tabular}

Note: ${ }^{*}=$ data from Nijenhuis et al. (Chap. 16, this volume).

$\mathrm{CO}_{2}$ spikes with a known ${ }^{13} \mathrm{C}$ content. The reported values were determined from duplicate analyses and the results were averaged to obtain a mean value and to calculate the standard deviation. The stable carbon isotopic compositions are reported in the delta notation against the PDB ${ }^{13} \mathrm{C}$ standard. Flash-pyrolysis GC-MS was performed using a FOM-4LX Curie point pyrolysis unit directly coupled to a Hewlett-Packard 5890 series II gas chromatograph, equipped with a fused silica capillary column $(30 \mathrm{~m} \times 0.25 \mathrm{~mm})$ coated with chemically bound DB 1701 (film thickness $0.25 \mu \mathrm{m}$ ); helium was used as carrier gas. The sample was pressed onto a flattened ferromagnetic wire (Curie temperature $610^{\circ} \mathrm{C}$ ) and heated by inductive heating in $0.15 \mathrm{~s}$ to the Curie temperature.

\section{RESULTS}

The most abundant compounds in the total lipid extracts of Samples 160-969E-6H-6, 32-33 cm, 160-969E-6H-6, 34-35 cm, and 160-969E-6H-6, 36-37 cm, are loliolides, sterols, $\mathrm{C}_{30}$ and $\mathrm{C}_{32}$ longchain diols, and $\mathrm{C}_{37}$ and $\mathrm{C}_{38}$ long-chain unsaturated methyl and ethyl alkenones (Fig. 1). GC-MS analysis of the total lipid fraction of Sample 160-969E-6H-6, 34-35 cm revealed that small amounts of isorenieratene (I; structures of selected compounds are given in the appendix and are referred to in the text, tables and figures by roman numerals) derivatives were present. For this reason, it was decided to analyze this particular sample in more detail, by separating the total lipid extract in an apolar and a polar fraction by column chromatography and by further fractionation of both the apolar and the polar fractions by thin layer chromatography. An aliquot of the unfractionated polar fraction was also desulfurized with Raney nickel to release sulfur-bound carbon skeletons.

\section{Polar Fraction}

Fractionation of the polar fraction by thin layer chromatography yielded six fractions (P1-P6), which allowed a better identification by GC-MS of compounds present in the polar fraction (Fig. 2B-E). The P1 fraction (not shown) is mainly comprised of the long-chain alkenones, including the $\mathrm{C}_{37: 2}$ alken-2-one and the $\mathrm{C}_{38: 2}$ alken-3-one. The P2 fraction (Fig. 2B) also contains long-chain alkenones but in addition another series of novel compounds, tentatively identified as $\mathrm{C}_{37}, \mathrm{C}_{38}$, and $\mathrm{C}_{39}$ di- and triunsaturated alken-2-ols (VI) and alken-3ols (VII) (Fig. 2B) are present. The mass spectrum of the silylated $\mathrm{C}_{37: 2}$ alken-2-ol (Fig. 3A) shows a molecular ion at $\mathrm{m} / \mathrm{z}$ 604. Characteristic fragment ions are observed at $\mathrm{m} / \mathrm{z} 514\left[\mathrm{M}^{+}-\mathrm{HOTMS}\right]$ and at $\mathrm{m} / \mathrm{z} 117\left[\mathrm{C}_{2} \mathrm{H}_{4} \mathrm{OTMS}\right]$. These mass spectral features are consistent with a position of the OTMS group at C-2 of a presumably linear $\mathrm{C}_{37}$ alkyl chain. The mass spectrum (Fig. 3B) of the silylated $\mathrm{C}_{38: 2}$ alken3 -ol has a molecular ion at $\mathrm{m} / \mathrm{z} 618$. The characteristic ions at $\mathrm{m} / \mathrm{z} 131$ $\left[\mathrm{C}_{3} \mathrm{H}_{6} \mathrm{OTMS}\right], \mathrm{m} / \mathrm{z} 589\left[\mathrm{M}^{+}-\mathrm{C}_{2} \mathrm{H}_{5}\right]$, and m/z 499 [M+ - HOTMS$\mathrm{C}_{2} \mathrm{H}_{5}$ ] suggest a position of the OTMS group at C-3 of a linear $\mathrm{C}_{38}$ 


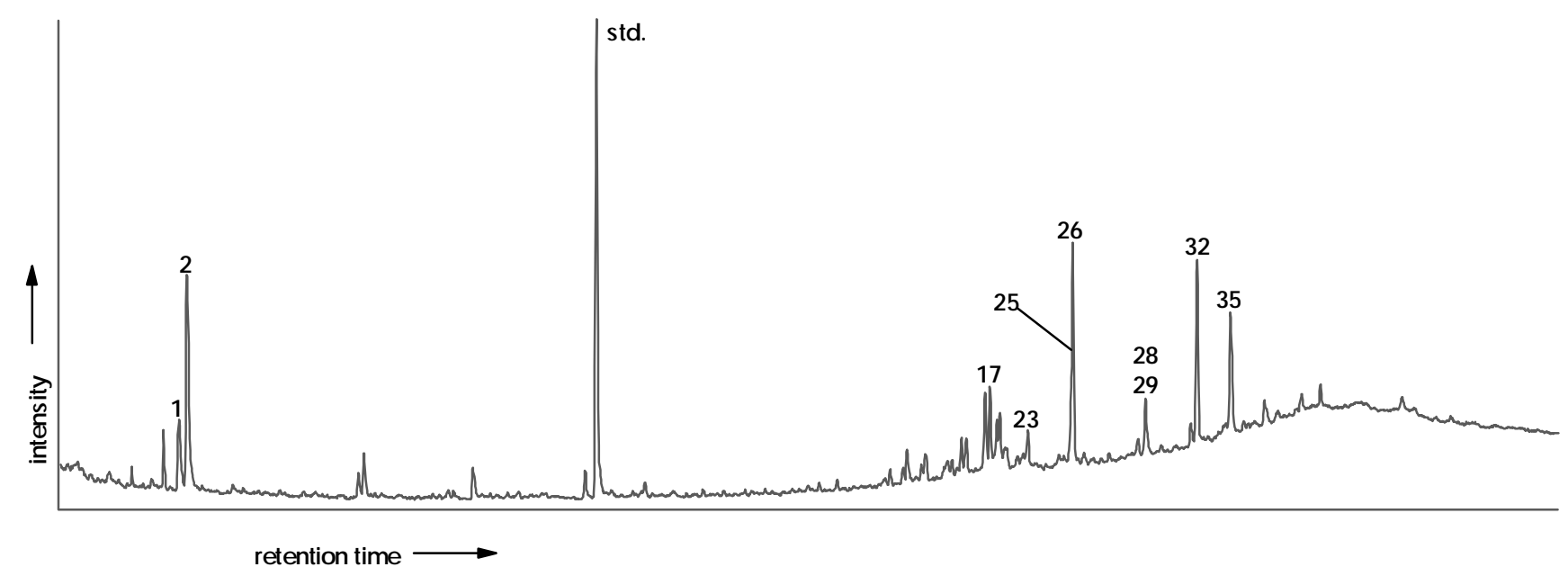

Figure 1. Gas chromatogram of the methylated and silylated total solvent extractable organic matter of Sample 160-969E-6H-6, 34-35 cm. Numbers refer to compounds listed in Table 2; std.=standard.

alkyl chain. It is impossible to assess the positions of the double bonds in these compounds by mass spectrometry. $\mathrm{C}_{27}$ and $\mathrm{C}_{29}$ midchain alkanols (VIII) were also tentatively identified in the $\mathrm{P} 2$ fraction (compounds 3 and 8 in Fig. 2B). Characteristic fragments resulting from $\alpha$-cleavages adjacent to a mid-chain OTMS group were observed for the coeluting $\mathrm{C}_{27}$ mid-chain alkanol isomers (Fig. 3C), positioning the OTMS group at C-11 (m/z 243 and m/z 327), C-12 (m/ z 257 and m/z 313), C-13 (m/z 271 and m/z 399) and at C-14 (m/z 285). The $\mathrm{C}_{29}$ mid-chain alkanol also consists of four isomers, with the OTMS group at positions C-10, C-11, C-12 and at C-14. These compounds are only present in trace amounts.

The P3 fraction (Fig. 2C) consists mainly of 4-methyl sterols and long-chain $\mathrm{C}_{30}$ and $\mathrm{C}_{32}$ keto-ols. Among the 4-methyl sterols, $4 \alpha, 23,24$-trimethyl-5 $\alpha$-cholest-22E-en-3 $\beta$-ol (dinosterol) is the most abundant. Small amounts of $\mathrm{C}_{26}$ and $\mathrm{C}_{28}$ alkanols are also present. Long-chain diols $\left(\mathrm{C}_{28}, \mathrm{C}_{30}\right.$ and $\left.\mathrm{C}_{32}\right)$ and the desmethyl sterols are present in the $\mathrm{P} 4$ fraction (Fig. 2D). $\mathrm{C}_{29}$ sterols are more abundant than the $\mathrm{C}_{27}$ and $\mathrm{C}_{28}$ sterols. The P5 fraction (Fig. 2E) contains $\mathrm{C}_{26}$, $\mathrm{C}_{28}, \mathrm{C}_{30}$, and $\mathrm{C}_{32} \alpha, \omega$-alkanediols. Another abundant compound is identified as a $\mathrm{C}_{30}$ alkan-1,13,30-triol (IX) (compound 31 in Fig. 2E) based on its retention time and comparison with published mass spectral data of a $C_{18}$ alkan-1,9,18-triol (Walton and Kolattukudy, 1972). The mass spectrum (Fig. 3D) shows two characteristic fragment ions at $\mathrm{m} / \mathrm{z} 359$ and $\mathrm{m} / \mathrm{z} 429$ resulting from alpha-cleavages adjacent to a mid-chain OTMS group at C-13. A molecular ion is not observed, but characteristic fragment ions are found at $\mathrm{m} / \mathrm{z} 671\left(\left[\mathrm{M}^{+}-\mathrm{CH}_{3}\right], \mathrm{m} / \mathrm{z}\right.$ $596\left[\mathrm{M}^{+}-\mathrm{HOTMS}\right], \mathrm{m} / \mathrm{z} 581\left[\mathrm{M}^{+}-\mathrm{HOTMS}-\mathrm{CH}_{3}\right], \mathrm{m} / \mathrm{z} 269[\mathrm{~m} / \mathrm{z}$ 359 - HOTMS] and m/z 339 [m/z 429 - HOTMS]. The P6 fraction (not shown) consists primarily of iso-loliolide and loliolide.

\section{Apolar Fraction}

Figure 4A shows the total ion current (TIC) trace of the total apolar fraction. This fraction was further separated by $\mathrm{Ag}^{+} \mathrm{TLC}$ to four fractions of increasing polarity. The most apolar fraction (A1) contains predominantly $n$-alkanes and lycopane (Fig. 4B). The dominant $n-\mathrm{C}_{22}$ alkane is a contaminant derived from the TLC plate. The $n$-alkanes range from $\mathrm{C}_{16}$ to $\mathrm{C}_{34}$ and maximize at $\mathrm{C}_{31}$. They show a strong odd-over-even carbon number preference of the higher homologs. Pristane and phytane are present as minor components. A fernene isomer, presumably fern-9(11)-ene, is the most dominant compound in the A2 fraction (Fig. 4C). Other compounds present in this fraction include several des-A-triterpenoids. The A3 fraction (Fig. 4D) consists mostly of desmethyl and 4-methyl sterenes and steradienes. Also detectable are a $\beta$-carotene derivative and a $C_{35}$ hopanoid thiophene (X). The major organic sulfur compounds, however, are present in the A4 fraction (Fig. 4E); they consist of unsaturated $\mathrm{C}_{25}$ and $\mathrm{C}_{30}$ highly branched isoprenoid (HBI) thiolanes (XI and XII, respectively). Nonsulfurized HBI alkenes occur in trace amounts. In the A4 fraction, two clusters of isomeric aromatic hydrocarbons that have not been previously identified are present. The mass spectra of the second cluster of isomers (compounds 21, 22 and 23; Figs. 4A and $4 \mathrm{E}$ ) all have a characteristic fragment ion at $\mathrm{m} / \mathrm{z} 133$ and a small molecular ion at m/z 542 (e.g., Fig. 5A). Hydrogenation of the apolar fraction resulted in the formation of isorenieratane (II) (for mass spectrum see Fig. 5B). The original isomers are, therefore, tentatively identified as di-unsaturated isorenieratene derivatives. The positions of the double bonds could not be determined unequivocally from the mass spectral fragmentation patterns. The isomeric aromatic hydrocarbons of the first cluster (compounds 17 and 18; Figs. 4A and 4E) also has $\mathrm{m} / \mathrm{z} 133$ as a characteristic fragment ion in their mass spectra (e.g., Fig. 5C), but the molecular ion is observed at $\mathrm{m} / \mathrm{z} 528$ and additional abundant fragments (m/z 342, 278, 252, and 237, most likely related to retro Diels Alder fragmentation reactions) do occur as well. Hydrogenation resulted in a shift of the molecular ion by 4 daltons (Fig. 5D). These compounds are tentatively identified as $\mathrm{C}_{40}$ cyclized isorenieratene derivatives (XIII) with two double bonds. The $\delta^{13} \mathrm{C}$ contents as determined by irm-GC-MS of the major components (compounds 17 and 18; Fig. 4E) of the first cluster (respectively, $15.6 \% \circ \pm 0.2$ and $-15.0 \% \circ \pm 0.3$ ) and of the major components (compounds 21, 22 and 23; Figs. 4A and 4E) of the second cluster (respectively, $13.8 \% \circ \pm 0.6 ;-14.1 \% \circ \pm 0.1$, and $-14.3 \% \circ \pm 0.6)$ are enriched relative to the $\delta^{13} \mathrm{C}$ content of algal lipids (e.g., $\mathrm{C}_{37: 2}$ alken-2-one; compound 32 in Figs. 2A and 2B; $-22.6 \% \pm \pm 0.3$ ).

The apolar fraction of Sample 160-969E-6H-6, 29-30 cm (Fig. 6A) shows that in this sample the $n$-alkanes are more abundant than in Sample 160-969E-6H-6, 34-35 cm. The novel isorenieratene derivatives (compounds 17, 18, 21, 22, and 23; Fig. 6A) are present in this sample as well, although not as abundant as in Sample 160-969E$6 \mathrm{H}-6,34-35 \mathrm{~cm}$. The apolar fraction of Sample 160-967C-6H-2, $35.3-36.8 \mathrm{~cm}$, also shows a higher abundance of the $n$-alkanes. In this sapropel, the novel isorenieratene derivatives (compounds 17, 18, 21, 22, and 23; Fig. 6B) occur as well.

\section{Desulfurized Polar Fraction}

The apolar fraction of Sample 160-969E-6H-6, 34-35 cm, obtained after desulfurization of the polar fraction is dominated by phytane and $\mathrm{C}_{25}$ and $\mathrm{C}_{30}$ highly branched isoprenoid alkanes (Fig. 7A). A number of isorenieratene-derived aromatic hydrocarbons, including 


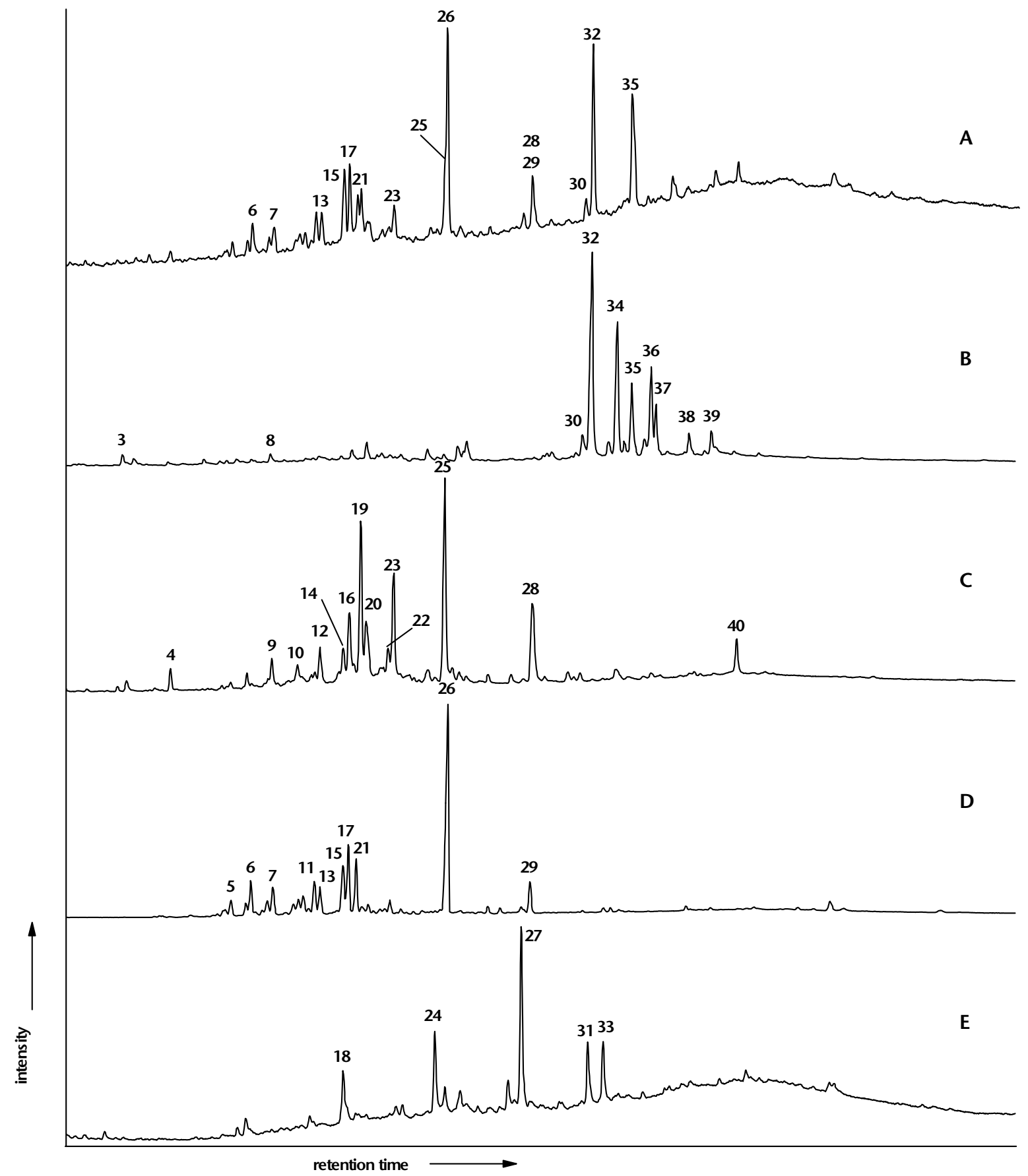

Figure 2. Partial gas chromatograms. A. Total extractable lipid extract. B. P2 fraction. C. P3 fraction. D. P4 fraction. E. P5 fraction of Sample 160-969E-6H-6, $34-35 \mathrm{~cm}$. Numbers refer to compounds listed in Table 2.

isorenieratane (II) and aryl isoprenoids (III) were also released (Fig. 7B). The presence of isorenieratane was confirmed by coelution with an authentic standard.

\section{Kerogens}

The kerogens of Samples 160-969E-6H-6, 29-30 cm, 160-969E$6 \mathrm{H}-6,34-35 \mathrm{~cm}$ and $160-967 \mathrm{C}-6 \mathrm{H}-2,35.3-36.8 \mathrm{~cm}$, were analyzed by flash pyrolysis GC-MS. All kerogen pyrolysates contain abundant $\mathrm{C}_{7}-\mathrm{C}_{30} n$-alkanes and $n$-alk-1-enes, prist-1-ene, $\mathrm{C}_{1}-\mathrm{C}_{4}$ alkylated ben- zenes, $\mathrm{C}_{1}-\mathrm{C}_{4}$ alkylated thiophenes and a series of methyl ketones. In addition, phenol and $\mathrm{C}_{1}-\mathrm{C}_{2}$ alkylated phenols, carbohydrate pyrolysis products (alkylated cyclopentenones, alkylated furans), alkylated naphthalenes and indenes, and in some cases alkylated aromatic nitrogen-containing products (e.g., pyrroles, pyrridines) are present in smaller relative concentrations. The pyrolysate of the kerogen from Sample 160-967C-6H-2, 35.3-36.8 cm, contains relatively more alkanes, alk-1-enes and methyl ketones than the other two pyrolysates. The pyrolysate of Sample 160-969E-6H-6, 29-30 cm, contains relatively more abundant aromatic pyrolysis products such as alkylated 

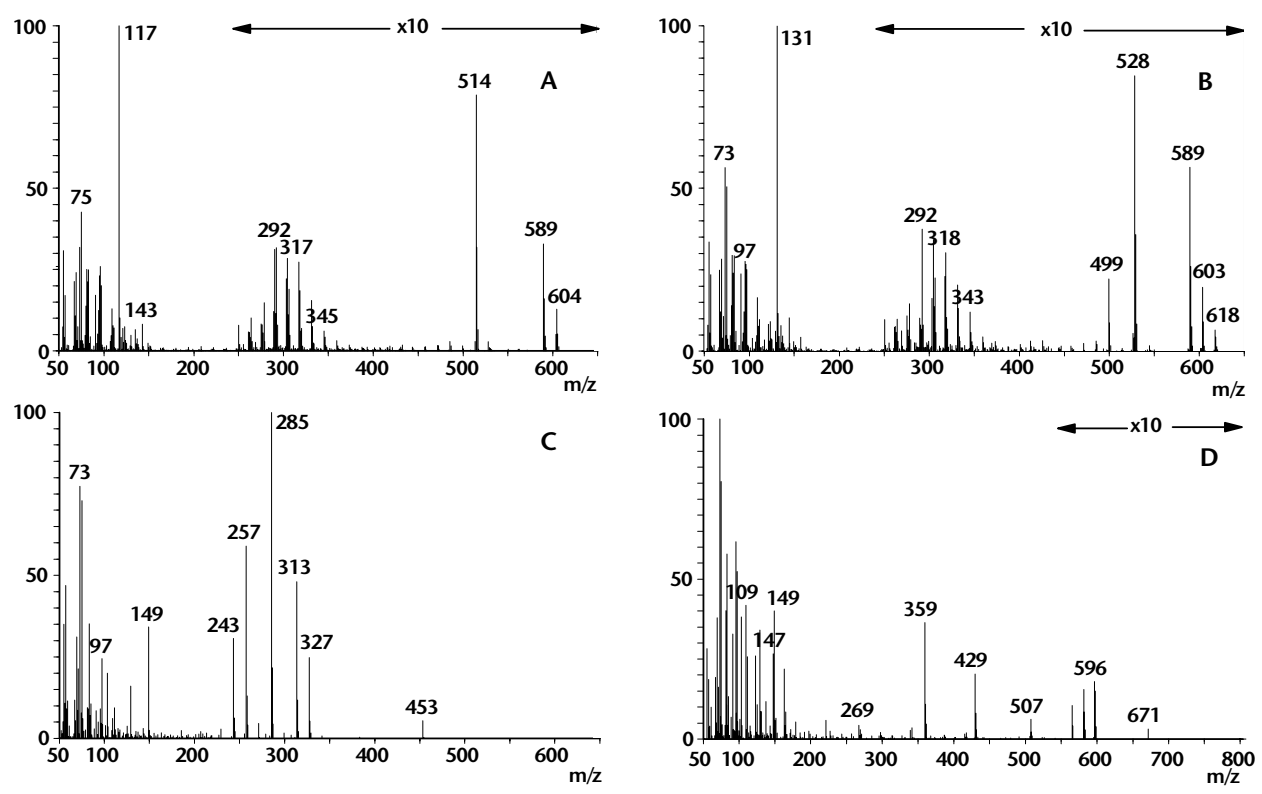

Figure 3. Mass spectra (corrected for background) of tentatively identified (A) $\mathrm{C}_{37: 2}$ alken-2-ol (VI); (B) $\mathrm{C}_{38: 2}$ alken-3-ol (VII); (C) A mixture of coeluting $\mathrm{C}_{27}$ mid-chain alcohol isomers (VIII); (D) $\mathrm{C}_{30}$ alkan-1,13,30-triol (IX). All alcohols were analyzed as their TMS ethers.

benzenes and phenols than that of Sample 160-969E-6H-6, 34-35 $\mathrm{cm}$. Although the alkylated thiophenes are abundant, they are not the major pyrolysis products as is the case with organic sulfur-rich Type II-S kerogens (Sinninghe Damsté et al., 1989b).

\section{DISCUSSION \\ Polar Lipids}

The major lipids in the solvent-extractable organic matter can be ascribed to a variety of algal sources. The long-chain alkenones are derived from haptophyte algae (Volkman et al., 1980; Marlowe et al., 1984) and are intensively studied because of their application as a sea-surface temperature proxy. $\mathrm{C}_{28}, \mathrm{C}_{30}$, and $\mathrm{C}_{32}$ alkane-1,15-diols have been found in eustigmatophyte algae (Volkman et al.,1992; Gelin et al., unpubl. data). Loliolide is a degradation product of the carotenoid fucoxanthin (Repeta, 1989; Klok et al., 1984). Dinosterol, dinostanol and other 4-methyl sterols attest to the presence of dinoflagellates (Boon et al., 1979; Robinson et al., 1984). The other sterols are less specific and may be derived from a variety of algal sources, possibly with a small contribution from higher plants (Volkman, 1986). The other, less abundant polar lipids cannot, at present, be unambiguously ascribed to specific sources. However, the tentatively identified long-chain alken-2-ols (VI) and alken-3-ols (VII) show great similarity in carbon chain length distribution and number of double bonds (Figs. 8A and 8B) with the long-chain alkenones (de Leeuw et al., 1980). A common origin (i.e., haptophyte algae) therefore seems likely. These long-chain alken-2-ols (VI) and alken-3-ols (VII) are formed either by diagenetic reduction of the long-chain unsaturated alkenones, or they are biosynthesized by organisms as such. So far they have not been found in haptophyte algae (Volkman, pers. comm., 1996; Versteegh, pers. comm., 1996). The $\mathrm{C}_{27}$ and $\mathrm{C}_{29}$ midchain alkanols (VIII) have been encountered in sediments from the Angola Basin (Versteegh, unpubl. data). The $\mathrm{C}_{30}$ alkane-1,13,30-triol (IX) has not been encountered before, although $\mathrm{C}_{30}$ and $\mathrm{C}_{32}$ alkan1,15,16-triols have been identified in several lacustrine samples (Bosch, unpubl. data). The origin of these compounds, therefore, remains unclear. A higher plant origin has been assigned to long-chain $\alpha, \omega$-alkanediols (Habermehl and Springer, 1983) but, based on car- bon isotope data, it has recently been suggested that they may also be derived from aquatic photoautotrophs (Huang et al., 1996). Only for the $\mathrm{C}_{26}$ and $\mathrm{C}_{28}$ alkan-1-ols can a higher plant origin be assigned.

\section{Hydrocarbons and Sulfur Compounds}

The apolar compounds make up only a minor fraction of the total solvent extractable organic matter. Hydrocarbons, present in trace amounts, include lycopane, which is thought to be synthesized by photoautotrophs in open marine systems (Wakeham et al., 1993). Fernenes have been ascribed to a bacterial origin (Ourisson et al., 1984). The distribution of the $n$-alkanes attests to a terrigenous, higher plant origin for these compounds (Eglinton and Hamilton, 1963). Other higher plant derived compounds are the des-A-triterpenoids (e.g., Huang et al., 1996). The desmethyl and 4-methyl sterenes and steradienes are diagenetic transformation products of sterols. $\mathrm{C}_{25}$ and $\mathrm{C}_{30}$ highly branched isoprenoids are mainly present as HBI thiolanes. These compounds derive from incorporation of reduced inorganic sulfur species during early diagenesis into highly branched isoprenoid alkenes (Sinninghe Damsté et al., 1989a; Kohnen et al., 1990a), which are biosynthesized by specific diatom species (e.g., Nichols et al., 1988; Volkman et al., 1994). Sulfur incorporation occurs both intramolecularly, leading to the formation of unsaturated $\mathrm{C}_{25}$ and $\mathrm{C}_{30} \mathrm{HBI}$ thiolanes, and intermolecularly, resulting in the formation of sulfur-rich macromolecular aggregates which contain $\mathrm{C}_{25}$ and $\mathrm{C}_{30} \mathrm{HBI}$ skeletons in relatively high amounts (Fig. 7A).

\section{Isorenieratene Derivatives}

Two clusters of compounds were identified, based upon mass spectral characteristics and hydrogenation experiments as diagenetic products of isorenieratene (I), the characteristic carotenoid of green sulfur bacteria. This assignment was confirmed by the relatively high ${ }^{13} \mathrm{C}$ content of these compounds since green sulfur bacteria fix $\mathrm{CO}_{2}$ via the reversed TCA cycle leading to biomass significantly enriched in ${ }^{13} \mathrm{C}$. Typically, isorenieratene derivatives are $10 \% 0-15 \%$ enriched relative to algal lipids (e.g., Sinninghe Damsté et al., 1993; Koopmans et al., 1996). Desulfurization of sulfur-rich macromolecular aggregates present in the polar fraction also yielded several isorenier- 


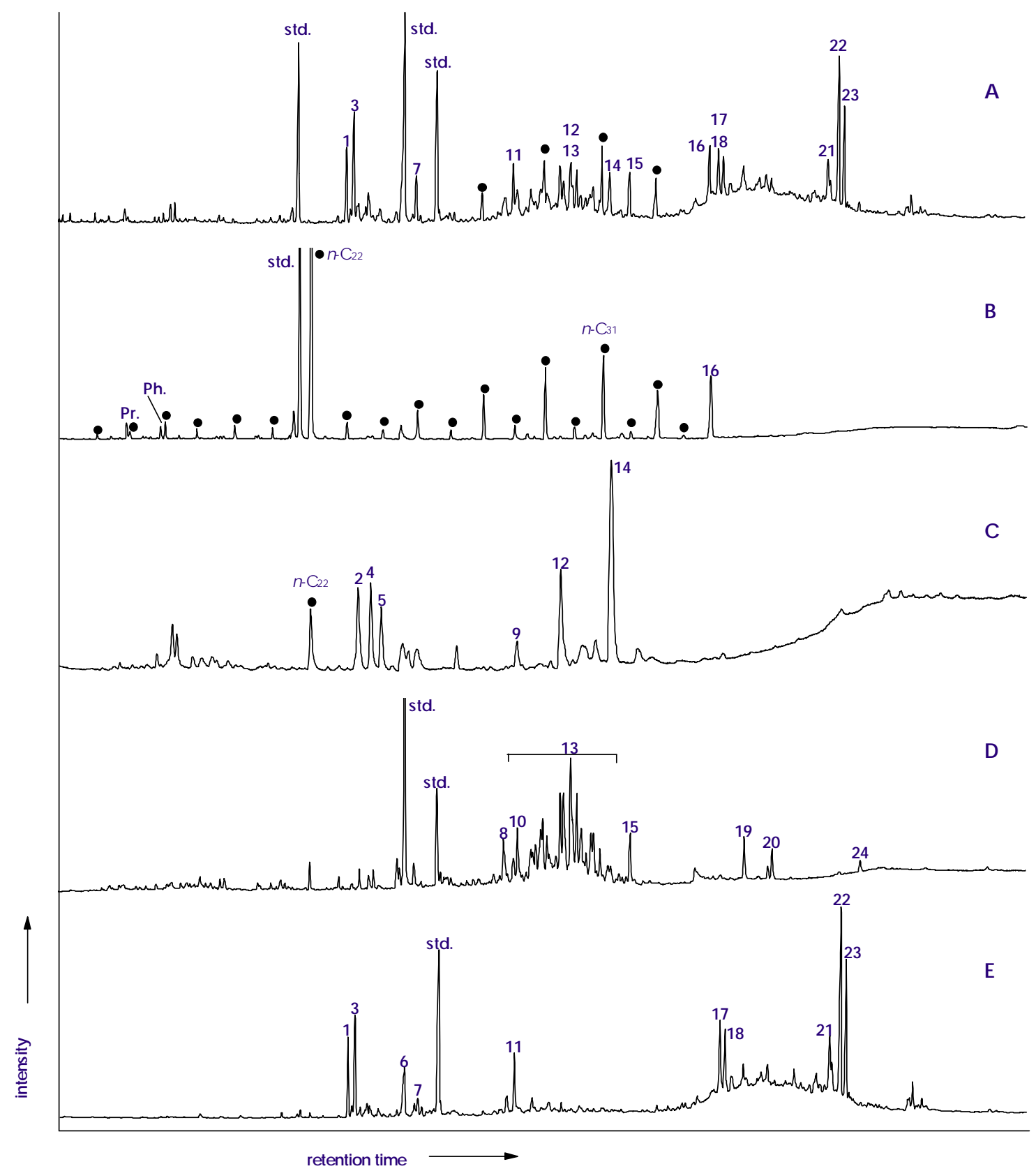

Figure 4. Gas chromatograms. (A) Total apolar fraction; (B) A1 fraction; (C) A2 fraction; (D) A3 fraction; (E) A4 fraction of Sample 160-969E-6H-6, 34-35 $\mathrm{cm}$. Numbers refer to compounds listed in Table 3; Pr.=pristane, Ph.=phytane; std.=standard.

atene derivatives (III, IV, V) including isorenieratane (II), indicating that isorenieratene has also become sequestered through sulfur bonding.

The presence of these biomarkers, indicative of anoxygenic photosynthesis, indicate that during the formation of these two sapropels, at least for part of the time, the chemocline was in the photic zone (typically $0-150 \mathrm{~m}$ ) of the eastern Mediterranean water column, and that, since these green sulfur bacteria need hydrogen sulfide, the eastern Mediterranean water column, at least for the two studied sites, was euxinic, comparable to the present-day Black Sea (Repeta et al., 1989). This provides the first direct evidence for an almost complete anoxic water column during sapropel formation. Since such conditions also occurred during deposition of sapropel 967C-6-2, contain- ing up to $8 \%$ TOC (Nijenhuis et al., Chap. 16, this volume), these conditions were not restricted to deposition of the most organic carbon-rich sapropels. Analysis of additional samples (work in progress) will shed light on the occurrence of photic zone euxinia in the eastern Mediterranean basin both in space and in time.

\section{Kerogens}

The flash pyrolysates of the kerogens indicate a major marine contribution to the organic matter. The dominant series of $n$-alkanes and $n$-alk-1-enes most likely derive from aliphatic cell wall biopolymers biosynthesized by marine algae (Gelin et al., 1996). The only pyrolysis products that may hint at a terrestrial contribution are phe- 

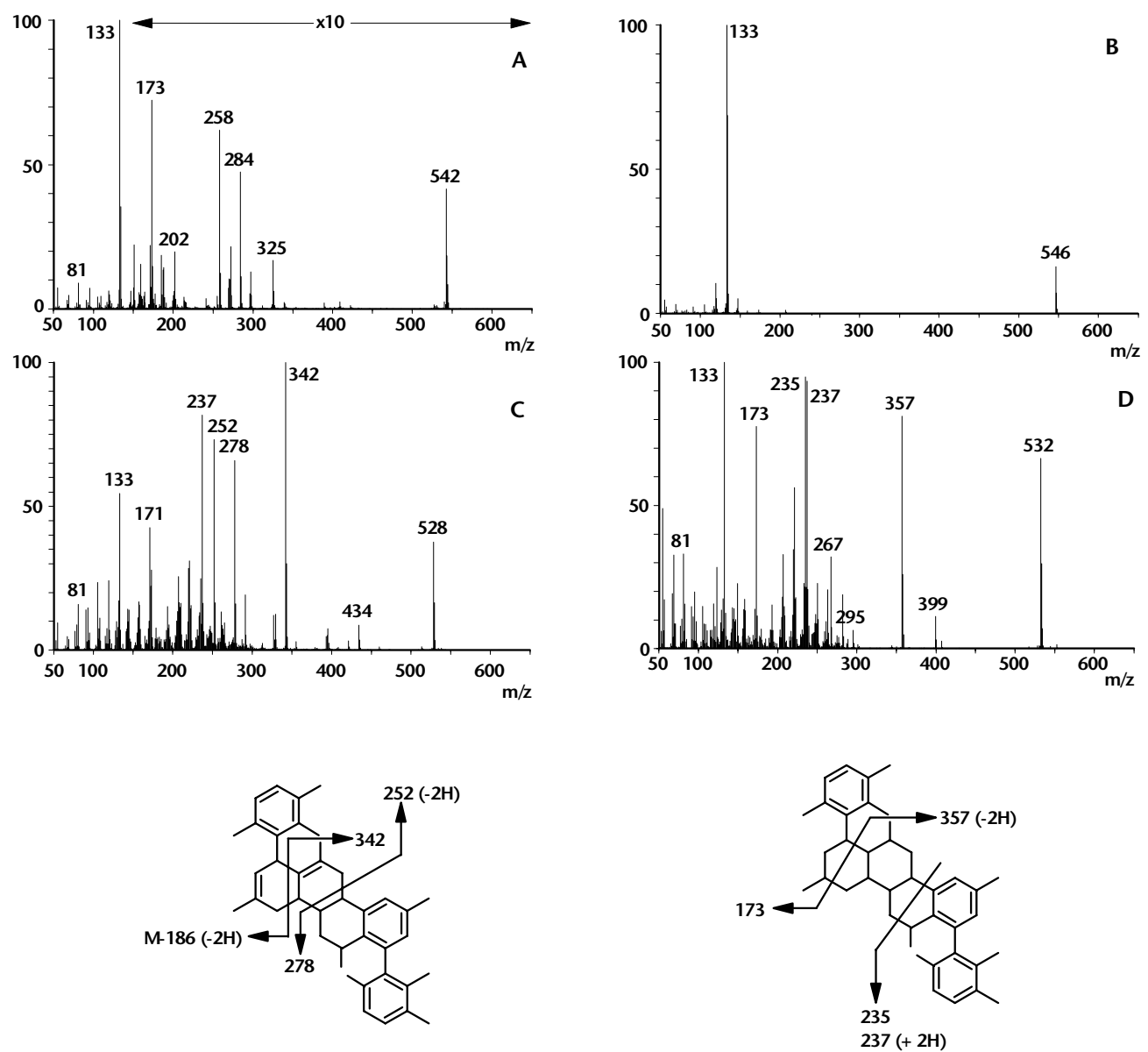

Figure 5. Mass spectra (corrected for background) of (A) Di-unsaturated isorenieratane derivative (Table 3, compound 22); (B) its hydrogenated counterpart: isorenieratane; (C) di-unsaturated cyclized isorenieratene derivative (Table 3, compound 17); (D) its counterpart in the hydrogenated apolar fraction. Structures indicate the presumed mass spectral fragmentations leading to the major fragment ions in mass spectra $\mathrm{C}$ and $\mathrm{D}$.

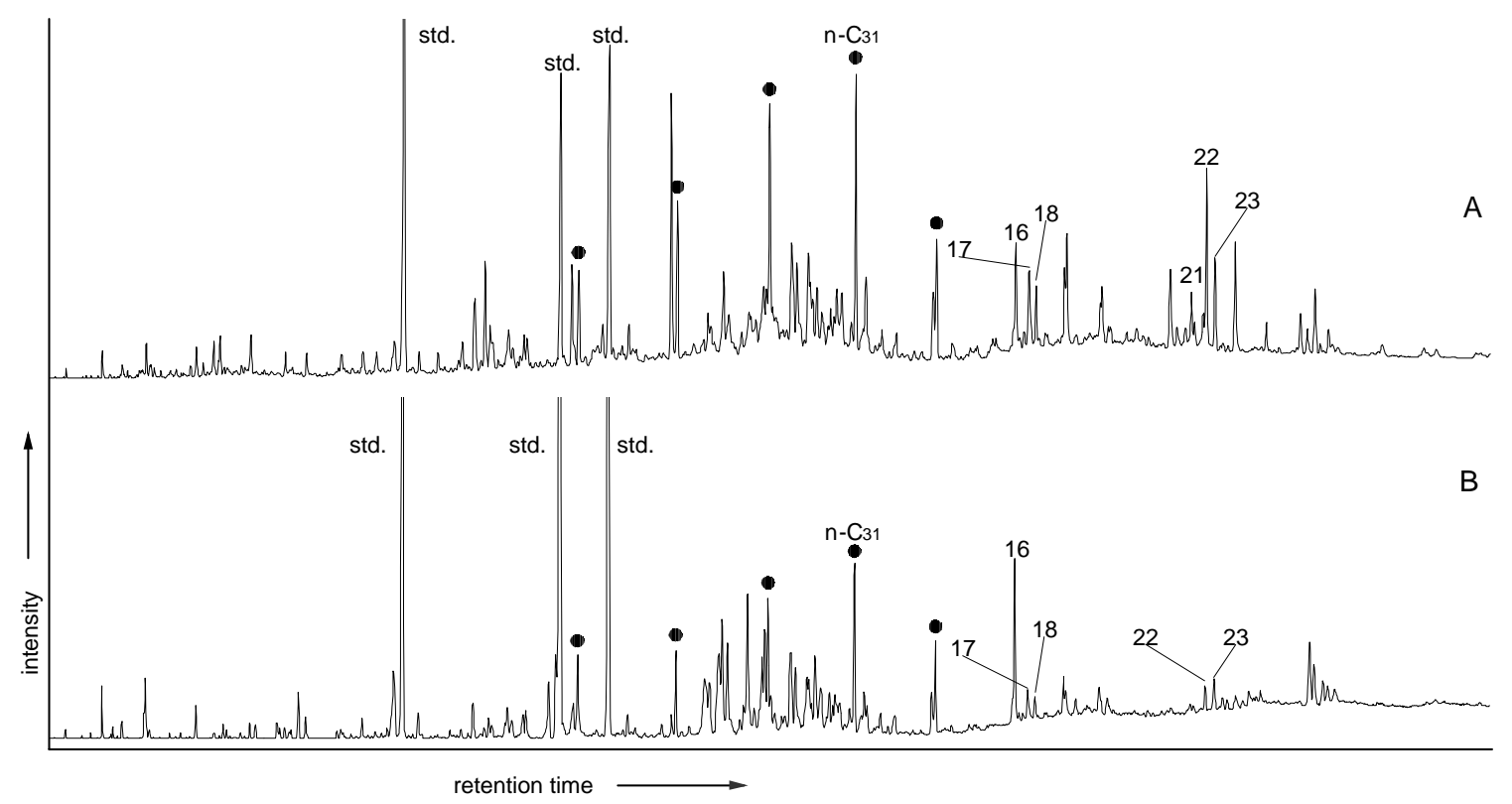

Figure 6. Gas chromatograms of the apolar fractions of (A) Sample 160-969E-6H-6, 29-30 cm; (B) Sample 160-967C-6H-2, 35.3-36.8 cm. Numbers refer to compounds listed in Table 3; std. $=$ standard. Solid circles indicate $n$-alkanes. 


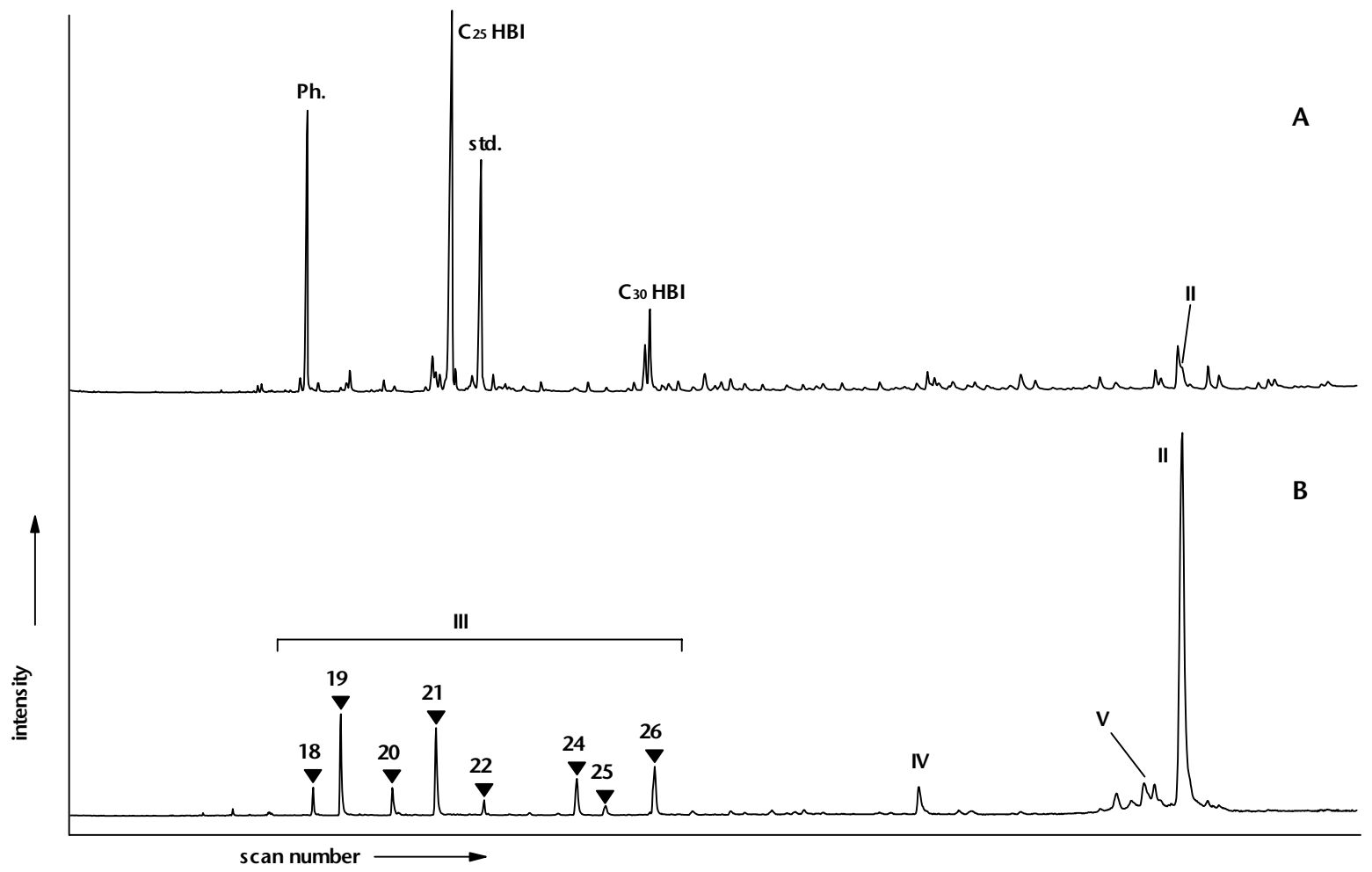

Figure 7. A. TIC of the desulfurized polar fraction. B. Released isorenieratene derivatives by desulfurization of the polar fraction of Sample 160-969E-6H-6, 34-35 cm, as revealed by the summed mass chromatogram of m/z 133+134. Filled triangles indicate aryl isoprenoids (III), numbers indicate total number of carbon atoms; std.=standard. $\mathrm{C}_{25} \mathrm{HBI}=\mathrm{C}_{25}$ highly branched isoprenoid alkane, $\mathrm{C}_{30} \mathrm{HBI}=\mathrm{C}_{30}$ highly branched isonrenoid alkane.

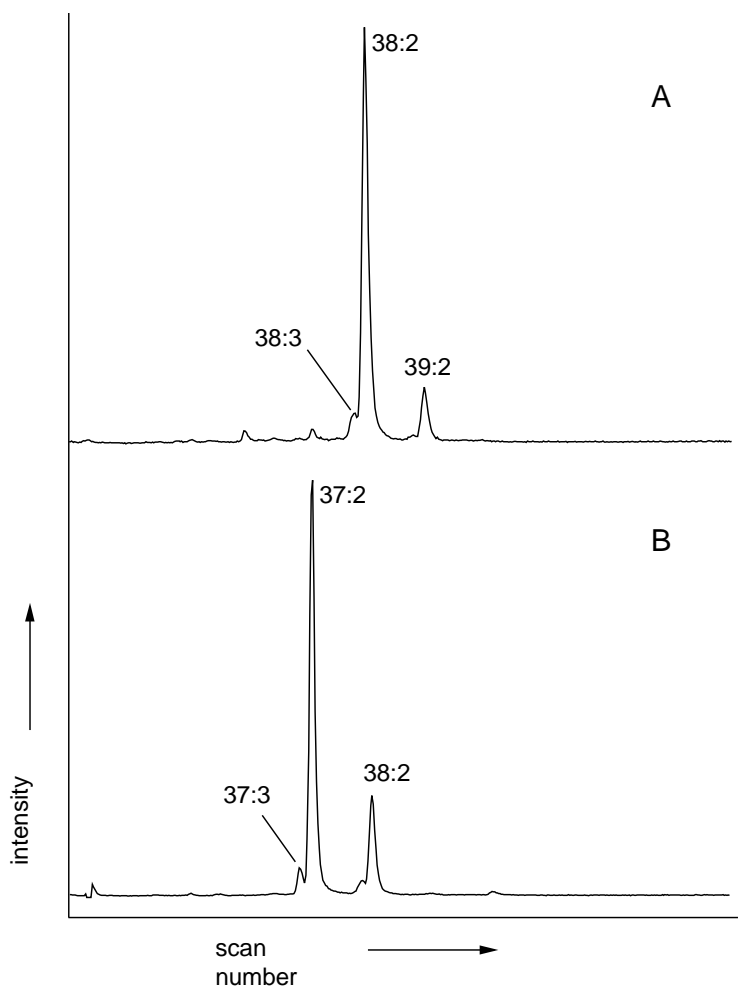

Figure 8. Partial mass chromatograms of (A) $\mathrm{m} / \mathrm{z} 131 ;$ (B) $\mathrm{m} / \mathrm{z} 117$, showing the distribution of the alken-3-ols (VII) and alken-2-ols (VI), respectively, in the P2 fraction of Sample 160-969E-6H-6, 34-35. Numbers indicate chain length and number of double bonds. nol and the alkylated phenol derivatives, since they may derive from modified lignin (Saiz Jimenez and de Leeuw, 1986). However, it has been demonstrated recently that they may have a marine origin as well (van Heemst et al., unpubl. data). The presence of relatively abundant alkylated thiophenes in the pyrolysates testifies to the reaction of reduced inorganic sulfur species with the sedimentary organic matter (presumably carbohydrates; van Kaam-Peters et al., unpubl. data) and indicates that the detrital iron available for pyrite formation was outcompeted by the production of reduced inorganic sulfur species. The presence of carbohydrate pyrolysis products indicates the presence of relatively labile organic matter in the sapropels.

\section{CONCLUSIONS}

The extractable and bulk organic matter of the sapropels studied is predominantly derived from a variety of algal sources. Specifically, for the extractable organic matter, a dominant input of dinoflagellates, haptophyte- and eustigmatophyte algae can be recognized. The presence of organic sulfur compounds indicates a significant incorporation of (bacterially) reduced inorganic sulfur species into organic molecules. The presence of isorenieratene-derived compounds, significantly enriched in ${ }^{13} \mathrm{C}$ relative to algal biomarkers, is consistent with an origin from isorenieratene biosynthesized by bacteria from the Chlorobiaceae. This provides unambiguous evidence for the presence of euxinic waters within the photic zone during the deposition of the exceptionally organic carbon-rich sapropel at Section 160$969 \mathrm{E}-6 \mathrm{H}-6$. The presence of isorenieratene derivatives in the sapropel at Section 160-967C-6H-2 with a much lower organic carbon content, indicates that the occurrence of photic zone anoxia was not confined to a limited number of exceptionally organic carbonrich sapropels but occurred more frequently both geographically and in time. 
Although a high surface water productivity is a prerequisite for a high carbon flux to the seafloor, it is suggested that for these sapropels the presence of an euxinic water column may have been an important factor for the accumulation of large amounts of organic carbon.

\section{ACKNOWLEDGMENTS}

The authors thank Dr. S. Schouten for performing the irm-GC-MS analyses. This work was supported by the Netherlands Organization for Scientific Research (NWO) by a PIONIER grant to JSSD and by a studentship to HJB. This is publication 970101 of the Netherlands Research School of Sedimentary Geology (NSG) and NIOZ publication 3142 .

\section{REFERENCES}

Boon, J.J., Rijpstra, W.I.C., de Lange, F., de Leeuw, J.W., Yoshioka, M., and Shimizu, Y., 1979. Black sea sterol—a molecular fossil for dinoflagellate blooms. Nature, 277:125-127.

Bradley, W.H., 1938. Mediterranean sediments and Pleistocene sea levels. Science, 88:376-379.

Calvert, S.E., 1983. Geochemistry of Pleistocene sapropels and associated sediments from the Eastern Mediterranean. Oceanol. Acta, 6:225-267.

Calvert, S.E., Nielsen, B., and Fontugne, M.R., 1992. Evidence from nitrogen isotope ratios for enhanced productivity during the formation of eastern Mediterranean sapropels. Nature, 359:223-225.

de Leeuw, J.W., van de Meer, F.W., Rijpstra, W.I.C., and Schenck, P.A., 1980. On the occurrence and structural identification of long chain ketones and hydrocarbons in recent and subrecent sediments. In Douglas, A.G., and Maxwell, J.R., Advances in Organic Geochemistry, 1979: Oxford (Pergamon Press), 219-227.

Demaison, G.J., and Moore, G.T., 1980. Anoxic environments and oil source bed genesis. AAPG Bull., 64:1179-1209.

Eglinton, G., and Hamilton, R.J., 1963. The distribution of alkanes. In Swain, T. (Ed.), Chemical Plant Taxonomy: London (Academic Press), 187-208.

Emeis, K.-C., and Shipboard Scientific Party, 1996. Paleoceanography and sapropel introduction. In Emeis, K.-C., Robertson, A.H.F., Richter, C., et al., Proc. ODP, Init. Repts., 160: College Station, TX (Ocean Drilling Program), 21-28.

Gelin, F., Boogers, I., Noordeloos, A.A.M., Hatcher, P.G., Sinninghe Damsté, J.S., and de Leeuw, J.W., 1996. Novel, resistant microalgal polyethers: an important sink of organic carbon in the marine environments? Geochim. Cosmochim. Acta, 60:1275-1280.

Grice, K., Gibbison, R., Atkinson, J.E., Schwark, L., Eckardt, C.B., and Maxwell, J.R., 1996. Maleimides (1H-pyrrole-2,5-diones) as molecular indicators of anoxygenic photosynthesis in ancient water columns. Geochim. Cosmochim. Acta, 60:3913-3924.

Habermehl, G., and Springer, G., 1983. Lankettige diole im Messeler Ölschiefer. Naturwissenschaften, 70:197-198.

Hayes, J.M., Freeman, K.H., Popp, B.N., and Hoham, C.H., 1990. Compound-specific isotopic analyses: a novel tool for reconstruction of ancient biogeochemical processes. In Durand, B., and Behar, F. (Eds.), Advances in Organic Geochemistry 1989. Org. Geochem., 16:11151128.

Hilgen, F.J., 1991. Astronomical calibration of Gauss to Matuyama sapropels in the Mediterranean and implication for the geomagnetic polarity time scale. Earth Planet. Sci. Lett., 104:226-244.

Howell, M.W., Thunell, R., Tappa, E., Rio, D., and Sprovieri, R., 1988. Late Neogene laminated and opal-rich facies from the Mediterranean region: Geochemical evidence for mechanisms of formation. Palaeogeogr., Palaeoclimatol., Palaeoecol., 64:265-286.

Huang, Y., Lockheart, M.J., Collister, J.W., and Eglinton, G., 1996. Molecular and isotopic biogeochemistry of the Miocene Clarkia Formation: hydrocarbons and alcohols. Org. Geochem., 23:785-801.

Kidd, R.B., Cita, M.B., and Ryan, W.B.F., 1978. Stratigraphy of eastern Mediterranean sapropel sequences recovered during DSDP Leg 42A and their paleoenvironmental significance. In Hsü, K.J., Montadert, L., et al., Init. Repts. DSDP, 42 (Pt. 1): Washington (U.S. Govt. Printing Office), 421-443.
Klok, J., Baas, M., Cox, H.C., de Leeuw, J.W., and Schenck, P.A., 1984. Loliolides and dihydroactinidiolide in a recent marine sediment probably indicate a major transformation pathway of carotenoids. Tetrahedron Lett., 25:5577-5580.

Kohnen, M.E.L., Sinninghe Damsté, J.S., Kock-van Dalen, A.C., ten Haven, H.L., Rullkötter, J., and de Leeuw, J.W., 1990a. Origin and diagenetic transformations of $\mathrm{C}_{25}$ and $\mathrm{C}_{30}$ highly branched isoprenoid sulphur compounds: further evidence for the transformation of organically bound sulphur during early diagenesis. Geochim. Cosmochim. Acta, 54:30533063.

Kohnen, M.E.L., Sinninghe Damsté, J.S., Rijpstra, W.I.C., and de Leeuw, J.W., 1990b. Alkylthiophenes as sensitive indicators of paleoenvironmental changes: a study of a Cretaceous oil shale from Jordan. In Orr, W.L., and White, C.D. (Eds.), Geochemistry of Sulfur in Fossil Fuels. ACS Symp. Ser., 249:444-485.

Koopmans, M.P., Köster, J., van Kaam-Peters, H.M.E., Kenig, F., Schouten, S., Hartgers, W.A., de Leeuw, J.W., and Sinninghe Damsté, J.S., 1996. Dia- and catagenetic products of isorenieratene: molecular indicators of photic zone anoxia. Geochim. Cosmochim. Acta, 60:4467-4496.

Marlowe, I.T., Brassell, S.C., Eglinton, G., and Green, J.C., 1984. Longchain unsaturated ketones and esters in living algae and marine sediments. In Schenck, P.A., de Leeuw, J.W., and Lijmbach, G.W.M. (Eds.), Advances in Organic Geochemistry 1983.Org. Geochem., 6:135-141.

Nichols, P.D., Volkman, J.K., Palmisano, A.C., Smith, G.A., and White, D.C., 1988. Occurrence of an isoprenoid $\mathrm{C}_{25}$ diunsaturated alkene and high neutral lipid content in Antarctic Sea-Ice diatom communities. $J$. Phycol., 24:90-96.

Ourisson, G., Albrecht, P., and Rohmer, M., 1984. The microbial origin of fossil fuels. Sci. Am., 251:34-41.

Passier, H.F., Middelburg, J.J., Van Os, B.J.H., and de Lange, G.J., 1996. Diagenetic pyritization under Eastern Mediterranean sapropels caused by downward sulphide diffusion. Geochim. Cosmochim. Acta, 60:751-763.

Pedersen, T.F., and Calvert, S.E., 1990. Anoxia vs. productivity: what controls the formation of organic-carbon-rich sediments and sedimentary rocks? AAPG Bull., 74:454-466.

Quandt, I., Gottschalk, G., Ziegler, H., and Stichler, W., 1977. Isotope discrimination by photosynthetic bacteria. FEMS Microbiol. Lett., 1:125128.

Repeta, D.J., 1989. Carotenoid diagenesis in recent marine sediments. II. Degradation of fucoxanthin to loliolide. Geochim. Cosmochim. Acta, 53:699-707.

Repeta, D.J., Simpson, D.J., Jørgensen, B.B., and Jannasch, H.W., 1989. Evidence for anoxygenic photosynthesis from the distribution of bacteriochlorophylls in the Black Sea. Nature, 342:69-72.

Robinson, N., Eglinton, G., Brassell, S.C., and Cranwell, P.A., 1984. Dinoflagellate origin for sedimentary $4 \alpha$-methylsteroids and $5 \alpha(\mathrm{H})$ stanols. Nature, 308:439-441.

Rohling, E.J. and Gieskens, W.W.C., 1989. Late Quaternary changes in Mediterranean intermediate water density and formation rate. Paleoceanography, 4:531-545.

Rossignol-Strick, M., 1985. Mediterranean Quaternary sapropels, an immediate response of the African Monsoon to variation of insolation. Palaeogeogr., Palaeoclimatol., Palaeoecol., 49:237-263.

Rossignol-Strick, M., Nesteroff, W., Olive, P., and Vergnaud-Grazzini, C., 1982. After the deluge: Mediterranean stagnation and sapropel formation. Nature, 295:105-110.

Saiz-Jimenez, C., and de Leeuw, J.W., 1986. Lignin pyrolysis products: their structures and their significance as biomarkers. Org. Geochem., 10:869876.

Sinninghe Damsté, J.S., Eglinton, T.I., de Leeuw, J.W., and Schenck, P.A., 1989a. Organic sulfur in macromolecular sedimentary organic matter. I: Structure and origin of sulfur-containing moieties in kerogen, asphaltenes and coal as revealed by flash pyrolysis. Geochim. Cosmochim. Acta, 53:873-889.

Sinninghe Damsté, J.S., Rijpstra, W.I.C., de Leeuw, J.W., and Schenck, P.A., 1988. Origin of organic sulphur compounds and sulphur containing high molecular weight substances in sediments and immature oils. In Matavelli, L., and Novelli, L. (Eds.), Advances in Organic Geochemistry 1987. Org. Geochem., 13:593-606.

Sinninghe Damsté, J.S., van Koert, E.R., Kock-van Dalen, A.C., de Leeuw, J.W., and Schenck, P.A., 1989b. Characterisation of highly branched isoprenoid thiophenes occurring in sediments and immature crude oils. Org. Geochem., 14:555-567. 
Sinninghe Damsté, J.S., Wakeham, S.G., Kohnen, M.E.L., Hayes, J.M., and de Leeuw, J.W., 1993. A 6,000-year sedimentary molecular record of chemocline excursions in the Black Sea. Nature, 362:827-829.

Skipski, V.P., Smolowne, A.F., Sullivan, R.C., and Barclay, M., 1965. Separation of lipid classes by thin-layer chromatography. Biochim. Biophys. Acta, 106:386-396.

Thunell, R.C., Williams, D.F., and Belyea, P.R., 1984. Anoxic events in the Mediterranean Sea in relation to the evolution of late Neogene climates. Mar. Geol., 59:105-134.

Volkman, J.K., 1986. A review of sterol markers for marine and terrigenous organic matter. Org. Geochem., 9:83-99.

Volkman, J.K., Barrett, S.M., and Dunstan, G.A., 1994. $\mathrm{C}_{25}$ and $\mathrm{C}_{30}$ highly branched isoprenoids in laboratory cultures of two marine diatoms. Org. Geochem., 21:407-414.

Volkman, J.K., Barrett, S.M., Dunstan, G.A., and Jeffrey, S.W., 1992. C $_{30^{-}}$ $\mathrm{C}_{32}$ alkyl diols and unsaturated alcohols in microalgae of the class Eustigmatophyceae. Org. Geochem., 18:131-138.
Volkman, J.K., Eglinton, G., Corner, E.D.S., and Sargent, J.R., 1980. Novel unsaturated straight-chain $\mathrm{C}_{37}-\mathrm{C}_{39}$ methyl and ethyl ketones in marine sediments and a coccolithophore Emiliania huxleyi. In Douglas, A.G., and Maxwell, J.R. (Eds.), Advances in Organic Geochemistry 1979: Oxford (Pergamon Press), 219-228.

Wakeham, S.G., Freeman, K.H., Pease, T.K., and Hayes, J.M., 1993. A photoautotrophic source for lycopane in marine sediments. Geochim. Cosmochim. Acta, 57:159-166.

Walton, T.J. and Kolattukudy, P.E., 1972. Determination of the structures of cutin monomers by a novel depolymerization procedure and combined gas chromatography and mass spectrometry. Biochem. 11:1885-1896.

Date of initial receipt: 16 January 1997

Date of acceptance: 19 June 1997

Ms 160SR-066

Table 2. Polar lipids identified in the sapropels.

\begin{tabular}{|c|c|c|c|}
\hline Peak $^{*}$ & Compound $^{* *}$ & Peak $^{*}$ & Compound $^{* *}$ \\
\hline 1 & Isololiolide & 21 & $\mathrm{C}_{28}$ alkan-1,15-diol \\
\hline 2 & Loliolide & 22 & $4 \alpha, 23(\mathrm{~S}), 24(\mathrm{R})$-trimethyl- $5 \alpha$-cholestan- $3 \beta$-ol \\
\hline 3 & $\mathrm{C}_{27}$ mid-chainalkanols (VIII) & 23 & 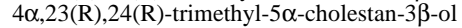 \\
\hline 4 & $\mathrm{C}_{26}$ alkan-1-ol & 24 & $\mathrm{C}_{28} \alpha, \omega$-alkanediol \\
\hline 5 & $5 \alpha$-cholest-22E-en-3 3 -ol & 25 & $\mathrm{C}_{30}$ keto-ols \\
\hline 6 & $5 \alpha$-cholestan-3 $\beta$-ol & 26 & $\mathrm{C}_{30}$ alkan-1,15-diol \\
\hline 7 & 24 -methyl-5 $\alpha$-cholest-22E-en- $3 \beta$-ol & 27 & $\mathrm{C}_{30} \alpha, \omega$-alkanediol \\
\hline 8 & $\mathrm{C}_{29}$ mid-chain alkanols (VIII) & 28 & $\mathrm{C}_{32}$ keto-ols \\
\hline 9 & $\mathrm{C}_{28}$ alkan-1-ol & 29 & $\mathrm{C}_{32}$ alkan-1,15-diol \\
\hline 10 & $4 \alpha$-methyl- $5 \alpha$-cholestan- $3 \beta$-ol & 30 & $\mathrm{C}_{37: 3}$ alken-2-one \\
\hline 11 & $\mathrm{C}_{29.2}$ sterol & 31 & $\mathrm{C}_{30}$ alkan-1,13,30-triol (IX) \\
\hline 12 & $4 \alpha, 24$-dimethyl- $5 \alpha$ cholest- $22 \mathrm{E}$-en- $3 \beta$-ol & 32 & $\mathrm{C}_{37: 2}$ alken-2-one \\
\hline 13 & 24 -ethyl- $5 \alpha$-cholest- $22 \mathrm{E}$-en- $3 \beta$-ol & 33 & $\mathrm{C}_{32} \alpha, \omega$-alkanediol \\
\hline 14 & unknown & 34 & $\mathrm{C}_{37.2}$ alken-2-ol (VI) \\
\hline 15 & 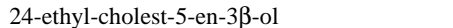 & 35 & $\mathrm{C}_{38 \cdot 2}$ alken-3-one \\
\hline 16 & $4 \alpha, 24$-dimethyl-5 $\alpha$-cholestan-3 $\beta$-ol & 36 & $\mathrm{C}_{38.2}$ alken-3-ol (VII) \\
\hline 17 & 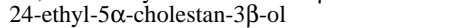 & 37 & $\mathrm{C}_{38: 2}$ alken-2-ol (VI) \\
\hline 18 & $\mathrm{C}_{26} \alpha, \omega$-alkanediol & 38 & $\mathrm{C}_{39 \cdot 2}$ alken-3-ol (VI) \\
\hline 19 & $4 \alpha, 23,24$-trimethyl- $5 \alpha$-cholest-22E-en- $3 \beta$-ol & 39 & unknown \\
\hline 20 & unknown & 40 & $\mathrm{C}_{39 \cdot 2}$ alken-2-ol (VI) \\
\hline
\end{tabular}

Notes: ${ }^{*}=$ peak numbers refer to Figures 1 and $2 ;{ }^{* *}=$ alcohols were analyzed as their TMS derivatives.

Table 3. Apolar lipids identified in the sapropels.

\begin{tabular}{rlrl}
\hline Peak $^{*}$ & \multicolumn{1}{c}{ Compound } & Peak $^{*}$ & \multicolumn{1}{c}{ Compound } \\
\hline 1 & C $_{25}$ HBI thiolane & 13 & steradienes \\
2 & des-A-triterpenoid & 14 & fern-9(11)-ene \\
3 & C $_{25}$ HBI thiolane & 15 & hop-21-ene \\
4 & des-A-triterpenoid & 16 & lycopane \\
5 & des-A-triterpenoid & 17 & isorenieratene derivative \\
6 & $\mathrm{C}_{30}$ HBI thiolane & 18 & isorenieratene derivative \\
7 & $\mathrm{C}_{30}$ HBI thiolane & 19 & unknown \\
8 & unknown & 20 & unknown $\beta$-carotene derivative \\
9 & unknown & 21 & isorenieratene derivative \\
10 & steradiene & 22 & isorenieratene derivative \\
11 & squalene & 23 & isorenieratene derivative \\
12 & unknown triterpenoid & 24 & $\mathrm{C}_{35}$ hopanoid thiophene \\
\end{tabular}

Note: ${ }^{*}=$ peak numbers refer to Figures 4 and 6. 
MOLECULAR PALEONTOLOGY

APPENDIX.

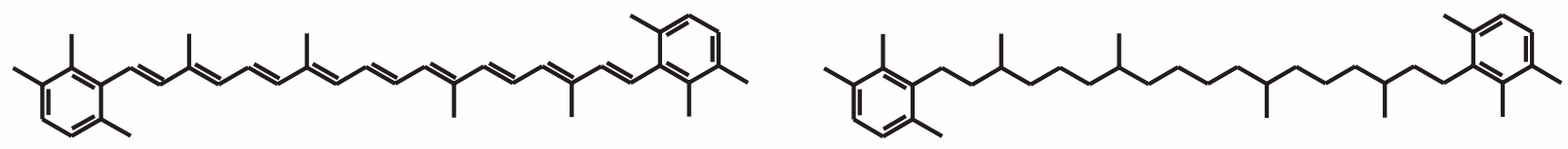

I

II
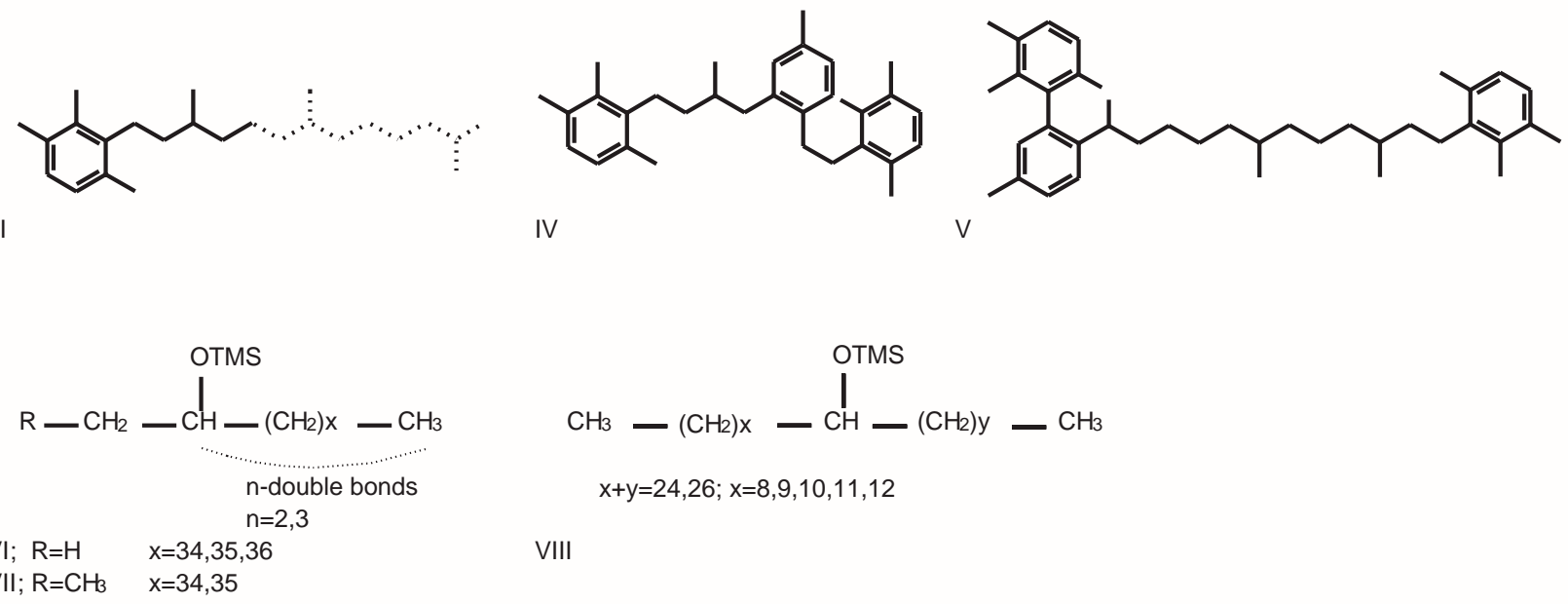

VI; $\mathrm{R}=\mathrm{H}=\mathrm{CH}_{3} \quad \mathrm{x}=34,35$<smiles>COCCCC(CCOC)C(O[Na])OCCOC</smiles>

IX

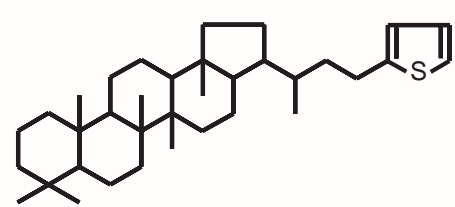

$x$

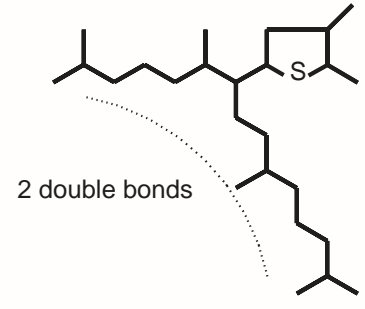

XI
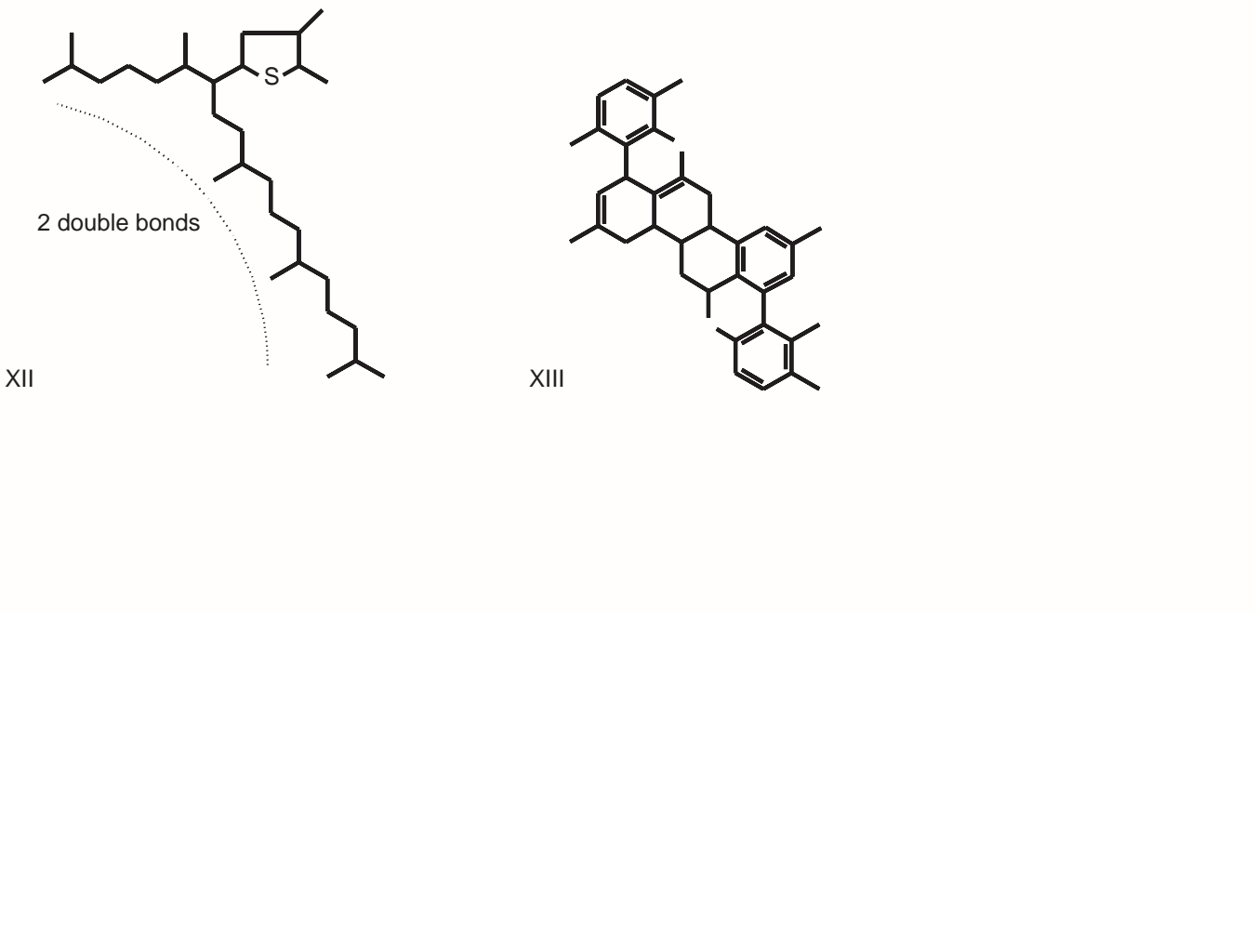

295 